in the age of Aspelut, about B.C. 700. In this period Egyptian influences predominated in art, as witness the small objects found in the Lion Temple and the building of the Temple of Isis. The Sun Temple must also be assigned to this period, as well as the foundations of the Temple of Ammon on the outskirts of the city. In the second period, which archæology assigns to 300 B.c., the Egyptian motives gave way entirely to Greek, as witness a small cameo of galloping horses found last year, and the semi-classical statues and general design of the baths just described. This result would seem to accord entirely with what is told of Ergamenes by Diodorus. The third period begins, apparently, with the Christian era, and seems, so far as it has been developed, to have been dominated rather by Roman ideals, and it lasted, so far as determined, down to the middle of the $4^{\text {th }}$ century, A.D., when there is a historical account of the invasion of a King of Axum.

The following axial bearings to magnetic north supplement those given by Prof. Garstang in his “Meroë," p. 26, n. 9 :-

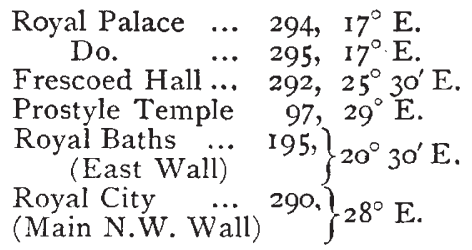

The magnetic deviation on December 27, I9ro, was determined by observation of Betelgeuse and $\epsilon$ Pegasi as follows :-

Axis of Temple of Ammon, 260.

$$
\begin{array}{ll}
\text { True Bearing : } & 294^{\circ} \\
\text { Magnetic Bearing : } 5 \mathrm{I}^{\circ} 9^{\prime \prime}
\end{array}
$$

The latitude and longitude of a point in this axis on the east wall of the Royal City are as follows :-

$$
\begin{aligned}
& \text { Lat. } \left.\quad{ }^{\circ} 6^{\circ} 57^{\prime}\right) \\
& \text { Long. } \left.33^{\circ} 42^{\prime}\right\}
\end{aligned}
$$

\section{COMMITTEE ON SIGHT TESTS FOR} SEAMEN. ${ }^{1}$

THE Departmental Committee appointed by the

Board of Trade, in June, Igro, has reported at considerable length on the questions submitted to it, and has, it may be hoped, brought the controversy concerning them to a conclusion. The Committee was appointed

"to inquire what degree of colour-blindness or defective form vision in persons holding responsible positions at sea causes them to be incompetent to discharge their duties, and to advise whether any and, if so, what alterations are desirable in the Board of Trade sight tests at present in force for persons serving or intending to serve in the Merchant Service or in fishing vessels, or in the way in which these tests are applied."

The Royal Society was represented on the Committee by Lord Rayleigh and by Profs. Gotch, Poynting, Rucker, and Starling, or, after the beginning of I9II, by Prof. Sherrington in the place of Prof. Starling; and the Committee

1 Report of the Departmental Committee on Sight Tests. (London: Wyman.) Price $4 \frac{1}{2} d$.

NO. 2227 , VOL. 89] examined a large number of men of science, of ophthalmic surgeons, and of practical seamen, and conducted a large number of experiments, some of them at Shoeburyness, where distant lights could be observed, and the essential conditions of actual service be reproduced.

The Committee obtained the assistance of colourblind persons in these experiments, and profited by their mistakes; and it heard the evidence, and examined the apparatus, of Dr. Edridge Green and other gentlemen. Finally, in the wool test for colour vision, it recommends the substitution of a dark brown skein for the red one hitherto employed, and, in the conduct of the test, the division of the whole collection of skeins into as many groups as there are test skeins. Each group should be composed of a fixed number of skeins which resemble the test skein, and a fixed number of those which colour-blind persons are liable to ccnfuse with it; and candidates should be required to divide each group into two parts, those which resemble the test skein, and those which do not.

As an addition to the test thus modified, the Committee recommends the use of a lantern designed for the purpose, and capable of showing either a single light, through a circular opening of $0^{\circ} 2$ inch in diameter, or two lights, through holes each $0^{\circ} 02$ inch in diameter, and separated by a distance of one inch. This lantern is placed at the level of the candidate's eyes, and the candidate and examiners stand alongside of it, and observe the lights as reflected in a plane mirror ten feet from the lamp. At this distance the angular magnitude of the large aperture is equal to that of a ship's light at 200 yards, and the angular magnitude of the two smaller apertures corresponds to that of a ship's lights at 2000 yards. These are sufficient to test imperfect vision, but are well within the limits of visibility of normal persons.

The Committee recommends that both this lantern and the modified wool test should be used in examining the colour vision of all candidates, and believes that it would be unnecessary to reexamine for colour vision any person who had passed them. It also recommends that the more rigid test for form vision ordered by the Board of Trade to come into operation in 1914 should be adhered to, that any officer holding a certificate whose visual acuteness in the better eye has fallen below half normal should be considered incompetent, and that steps be taken to impress upon parents and guardians, and upon shipowners taking apprentices, the desirability of submitting boys to an expert examination before they adopt the sea as a profession.

A highly important further recommendation is that, whenever judicial inquiries into the causes of shipping casualties are being held, witnesses who give evidence as to the nature and position of coloured signals or lights should always be tested for colour and form vision. The report is signed by all the Commissioners, but Sir Norman Hill appends a memorandum dissenting from certain portions of the recommendations with regard to form vision. 